\title{
Development of Artificial Neural Network Model for Estimation of Salt Fields Productivity
}

\author{
Indra Cahyadi *, Heri Awalul Ilhamsah, Ika Deefi Anna \\ Department of Industrial Engineering, Engineering Faculty, Universitas Trunojoyo Madura, Indonesia \\ Jl. Raya Telang, Kamal, Perumahan Telang Inda, Telang, Bangkalan, Indonesia \\ *Corresponding author: indra.cahyadi@trunojoyo.ac.id
}

\section{ARTICLE INFO}

\section{Article history}

Received June 18, 2019

Revised August 6, 2019

Accepted August 16, 2019

Available Online August 31, 2019

Keywords

Artificial Neural Network

Forecasting

Predictive Modeling

Salt fields

\begin{abstract}
In recent years, Indonesia needs import millions of tons of salt to satisfy domestic industries' demand. The production of salt in Indonesia is highly dependent on the weather. Therefore, this article aims to develop a prediction model by examining rainfall, humidity, and wind speed data to estimate salt production. In this research, Artificial Neural Network (ANN) method was used to develop a model based on data collected from Sumenep Madura Indonesia. The model analysis used the complete experimental factorial design to determine the effect of the ANN parameter differences. Furthermore, the selected model performance compared with the estimate predictor of HoltWinters. The results presented that ANN-based models were more accurate and efficient for predicting salt field productivity.
\end{abstract}

This is an open-access article under the CC-BY-SA license.

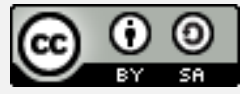

\section{Introduction}

Indonesian Industry Ministry stated that national salt consumption growth by industrial raw materials and household needs. Industrial salt demand reached 3.7 million in 2018 and increased by $76.19 \%$ from 2017 . However, domestic salt production cannot meet the national demand. Therefore, almost $100 \%$ of national industrial salt demand gathered from international markets. Dependence on the imported salt indicates Indonesia's inability to produce salt and can not meet the demand for domestic salt [1]. In general, salt production in Indonesia is provided by salt farmers utilizing salt fields [2]. Salt production in Indonesia comes from the evaporation of seawater contained in the salt pond. Salt production is highly dependent on climate and weather. According to Adiraga and Setiawan [3], Indonesia's salt supply chain and distribution channel were less efficient than other countries. Furthermore, the salt industry was a strategic industry that must be appropriately managed. However, the length of the supply chain process inhibited the potential of salt production in Indonesia.

Therefore, the salt industry in Indonesia must have adequate supply chain synchronization among the agents [4] [5]. The way to achieve this goal was to maximize 
production and estimate the right time to produce salt [6] [7] [8] [9]. Several studies have been conducted in salt supply chain management in Indonesia. Dharmayanti, et al. [10] analyzed the national salt availability system based on self-sufficiency policy. Dynamic system analysis was used to compare simulation results from different policies. The results indicated that Indonesia has not been able to achieve sustainable salt selfsufficiency. Herman, et al. [11] used the Analytic Network Process (ANP) to get potential risk factors of the national salt crisis. These factors included weather, trade regulations, innovation, salt prices, and company policies.

Perbangsa, et al. [12] studied the construction of a web-based supply chain model and determined the salt industries' information flow in Indonesia. The research showed that the salt supply chain model was pull-based. The information flow process was greatly influenced by wholesale demand. The model defined that supply chain information flow was interrupted due to difficulties in getting demand levels, raw material inventory data, and salt production progress. Furthermore, the object of this study was to determine the impact of rainfall, salt pond width, and the number of salt farmers on salt production in Pati, Central Java [3]. This study used regression analysis to resolve the relationship between these three factors toward the productivity of salt in Pati. As a result, rainfall had a negative effect. The number of farmers and pond area had a positive effect on salt production.

Based on the previous study, the salt production process was affected by weather conditions, salt fields, and the number of farmers. However, the application of quantitative techniques to estimate salt productivity in a certain period was not found. Different from previous studies, this paper aims to establish a salt land productivity estimates are accurate. This study proposed the Artificial Neural Network (ANN) model to estimate the productivity of salt fields. The advantage of the ANN method is the low risk of failure to solve prediction problems, especially in estimating non-linear relationships [13][14]. Furthermore, the results of this study contribute to the improvement of the supply chain performance and the prediction of salt.

\section{Methods}

ANN method is a data processing system, which mimics the human nervous system. A neural network is an interrelated network of processing layers where independent computations typically start from the first layer (input layer) and pass on to the next layers that pass the results to another layer (hidden layers) (Fig. 1). This process continues to progress into the last layer (output layer) [13] [15] [16] .

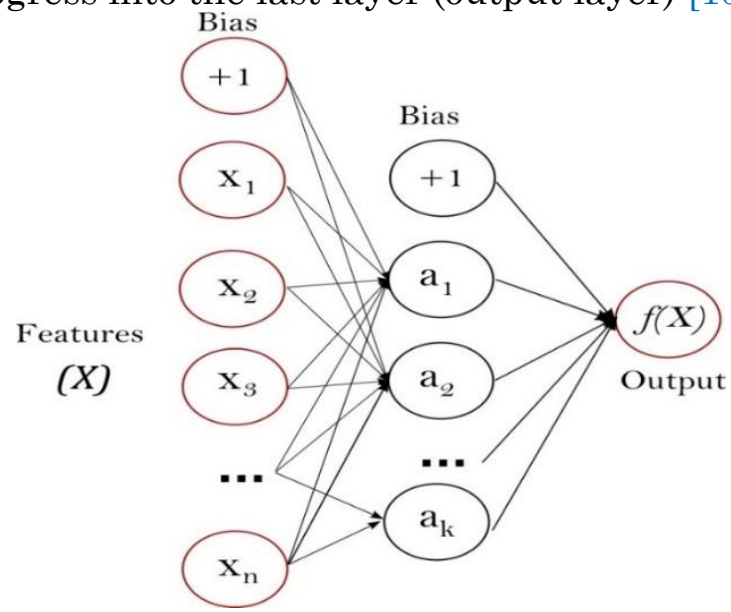

Fig. 1. The topology of the three-layer feed-forward neural network [15] 


\subsection{Data Collection}

In this study, the forecasting model estimated the total production of salt fields in month $t$ (period). ANN method consisted of four variables: vast salt fields, amount of monthly production, amount of sunlight term, wind speed, and temperature in Sumenep, Madura Indonesia. Weather conditions were as input data. The output was the level of productivity of salt fields were measured from the average land area of salt and production per month in Sumenep, Madura, Indonesia. These four data sets were plotted against the year in Table 1 . Those data sets of time series were used to generate data training and testing. Each of these data sets to divided into training and testing data by a ratio of 70:30 [17].

The next step was to determine the best model based on parameters, i.e., Learning rate, momentum, epoch, and desired error were set in the data training. After the modeling process in the previous step was done. The performance test using testing data on the selected model was conducted. Furthermore, this study used experiments to determine the learning rate and learning momentum that give satisfactory results.

Table 1. Research data sets yearly in Kalianget Sumenep, Indonesia

\begin{tabular}{ccccc}
\hline Year & $\begin{array}{c}\text { Productivity } \\
\text { (ton/ha) }\end{array}$ & $\begin{array}{c}\text { Rainfall } \\
(\mathrm{mm})\end{array}$ & Humidity $(\%)$ & Wind Speed $(\mathrm{m} / \mathrm{s})$ \\
\hline 2010 & 0.40 & 1943.28 & 80.59 & 4.26 \\
\hline 2011 & 21.57 & 1204.95 & 83.85 & 3.35 \\
\hline 2012 & 50.73 & 1019.96 & 82.90 & 3.12 \\
\hline 2013 & 27.54 & 1066.77 & 82.29 & 2.73 \\
\hline 2014 & 59.14 & 946.60 & 79.33 & 3.15 \\
\hline 2015 & 59.40 & 705.54 & 77.53 & 3.04 \\
\hline 2016 & 6.52 & 1990.84 & 82.09 & 2.36 \\
\hline 2017 & 115.86 & 2053.97 & 81.27 & 2.63 \\
\hline 2018 & 130.44 & 692.00 & 78.42 & 2.79 \\
\hline
\end{tabular}

Source: Processed from data of BPS Sumenep and BMKG

The results were considered satisfactory when those who gave the least Root Mean Squared Error (RMSE). In the last step, the optimal model was used to test and compare the forecasting performance based on ANN and Holt-Winters predictors using the time-series data set as the input. This study used secondary data obtained from the Trade and Industrial Agency of Sumenep Madura, Central Bureau of Statistics Indonesia (BPS Sumenep), and the Indonesian Agency for Meteorology, Climatology, and Geophysics (BMKG). The data for the ANN method consisted of four variables: data of the area of salt fields and monthly production yields collected from the Trade and Industrial Agency of Sumenep Madura, BPS, and data of the amount of sunlight duration, wind speed, and temperature Sumenep Madura received from BMKG. Based on the historical data and the performance of each ANN model, the optimal forecasting model for salt field productivity was selected through a minor Root Mean Squared Error (RMSE).

\subsection{Data Analysis}

The ANN models in this study were developed using the Fast Artificial Neural Network (FANN), which has some features to construct optimal training algorithm and activation functions [18], [19]. FANN determined whether resilient propagation or backpropagation was the optimal training algorithm for data training. The objective of back- 
propagation training was to adjust the weights to minimize the error function. In this algorithm, the weights were updated after a training pattern that means weights are updated many times during a single epoch. On each iteration, the new weights are given by equation (1).

$w_{s t}^{\text {new }}=w_{s t}^{\text {old }}+\Delta w_{s t}=w_{s t}^{\text {old }}+\eta \frac{\partial E}{\partial w_{s t}}$

where, $w_{s t}$ is the weight change between neuron-s to neuron $-t$ in the next layer, and $\eta$ is the learning rate [17] [19].

The objective of the resilient-propagation training algorithm was to adjust the weights of the network according to signal error propagation. In this algorithm, the weight updates were controlled for each connection during the training process. In each iteration, the new weights are given by equation (2).

$w_{i j}^{(t+1)}:=w_{i j}^{(t)}+\Delta w_{i j}^{(t)}$

and the step-sizes are computed as (equation (3))

$\Delta w_{i j}^{(t)}:=-\operatorname{sign}\left(\frac{\partial E^{(t)}}{\partial w_{i j}}\right) \Delta_{i j}^{(t)}$

The "sign" operator returns +1 if its argument was positive, -1 if the argument was negative, and 0 otherwise [20].

FANN also included a feature to select the optimal activation functions based on the given parameters. The activation functions are defined for a group of neurons by the hidden activation function, output function, or a single neuron by input an activation function and the steepness of an activation function. Excel spreadsheet software with additional templates ware used to conduct experiments to determine optimal ANN parameters and execute Holt-Winters calculation to forecast data points in a seasonal series.

Seven models were initially proposed as the foundation of salt field productivity forecast model development, each of which was described as follows: Model 1: This model used 1 input variable with input neuron (x); Model 2: This model used 1 input variable with input neuron (y); Model 3: This model used 1 input variable with input neuron (z); Model 4: This model used 2 input variables with input neurons (x) and (y); Model 5: This model used 2 input variables with input neurons (x) and (z); Model 6: This model used 2 input variables with input neurons (y) and (z); Model 7: This model used 3 input variable with input neurons (x), (y) and (z). Where $x$ is average sunlight duration in month $t ; y$ is the average wind speed in month $t ; z$ is the average temperature in month $t$.

\section{Results and Discussion}

There were five parameters used in the FANN model. The parameters include the number of hidden layers equals 1 . The number of neurons in that layer equals 2 , the learning rate of 0.7 , the momentum of 0.1 , and the maximum epoch of 50,000 epoch. All models were trained and tested with 1 hidden layer and 2 neurons in its hidden layer. According to Heaton [21], one hidden layer was sufficient to resolve most neural network problems. Two neurons in that layer were considered to give decent performance since it lies between the neurons' mean in the input and output layers and the upper bound on 
the number of hidden neurons that shall not result in over-fitting [22]. The comparison of training results from each model is summarized in Table 2. Model 7 was selected based on the experiment because it is more optimal than the other proposed models.

Table 2. Comparison Of Optimum ANN Methods For Each Model

\begin{tabular}{|c|c|c|c|c|}
\hline \multirow{2}{*}{ Model } & \multicolumn{4}{|c|}{ ANN Method } \\
\hline & Train Method & Hidden & Output & MSE \\
\hline 1 & RPROP & SIGMOID & $\begin{array}{c}\text { SIGMOID_SYMMETRIC_STEP } \\
\text { WISE }\end{array}$ & 0.0043 \\
\hline 2 & QUICKPROP & SIGMOID & COS_SYMMETRIC & 0.0094 \\
\hline 3 & BATCH & SIGMOID & COS_SYMMETRIC & 0.0089 \\
\hline 4 & QUICKPROP & ELLIOT & COS_SYMMETRIC & 0.0118 \\
\hline 5 & RPROP & GAUSSIAN & SIN_SYMMETRIC & 0.0029 \\
\hline 6 & RPROP & $\begin{array}{c}\text { SIGMOID_STEPWI } \\
\text { SE }\end{array}$ & LINEAR_PIECE_SYMMETRIC & 0.0021 \\
\hline 7 & QUICKPROP & SIGMOID & COS_SYMMETRIC & 0.0005 \\
\hline
\end{tabular}

The selected ANN methods for Model 7 were summarized as follows: Quick propagation: This algorithm adjusts the network's weights according to signal error propagation. The objective is to maximize the parameters to achieve good results for many problems. Sigmoid symmetric activation function: The sigmoid produces an "S" shaped curve to recognize nonlinearity in the model. The output range is between zero and one (equation (4)). Cos symmetric activation function: this periodical cosinus activation function is required over the activation range for smoother control. The output range is between -1 and 1 (equation (5)). The obtained MSE value from the training procedure was convincing. Any model with an MSE value, which was significantly less than 0.001 , could predict the value in a given period [23].

$$
\begin{aligned}
& y=\frac{1}{1+e^{-2 x S}} \\
& y=\cos x S
\end{aligned}
$$

The most important parameter of an artificial neuron network was the value of the learning rate. The training result was more reliable when the learning rate is low; however, optimization needed much time because the required steps to achieve the minimum value of the loss function were tiny. If the learning rate was high, then training may not be satisfying because the optimizer was to overshoot the minimum and make a worse error rate. Another critical parameter that needs to be set was the learning momentum. Learning momentum enabled the estimation of a certain weight and the search of the global minimum at a given time [21] [23] [24]. To get satisfying results, a model must go through the training process in the ANN method, which was usually tedious and based on trial and error [25]. This study used the design of experiments training to determine a reliable learning rate. The learning rate parameter in this design of experiments was set between 0.3 and 0.9 [26].

In general, the broader data set of the neural network model is more accurate. However, the data collection process requires some time. The model development process is inefficient if too much time was wasted on building the database. Therefore, the idea in this study was to develop a model capable of learning from an available amount of training data. The design of experiments was prepared to obtain learning momentum 
value that can accelerate the training process of the ANN model. This study's momentum parameter was set between 0.5 and 0.9 [23] [26].

Model 7 was considered satisfactory because it gave the least RMSE. This study proposed to investigate the impacts of learning rate and momentum values on the ANN model. It was implemented the performance complete factorial parameter design. Each of the parameters has low and high levels for different neural networks to be created and tested. Table 3 summarizes the parameter designs used in this study.

Moreover, this study applies a midpoint in the low and high experiment levels to explore whether the relation between low and high levels consists of a non-linear reaction. By adding a midpoint between the low and high levels, curvature between the two points can be inspected [23], [27]. Therefore, this study added 2 central points to inspect the low and high levels in the experiment. The effect of learning rate and momentum parameter value variations is described in Table 3.

Table 3. Neural Network Parameter Design for Model 7

\begin{tabular}{cccc}
\multirow{2}{*}{ Item } & \multirow{2}{*}{ Parameter JST } & \multicolumn{2}{c}{ Level } \\
\cline { 3 - 4 } A & Learning Rate & 0.3 & 2 (High) \\
B & Momentum & 0.5 & 0.9
\end{tabular}

Table 4 represents that the use of learning rate and momentum variations influence the final forecast. The RMSE validation data obtained when the learning level was at level two is 0.9. The constant momentum at level 1 was 0.5. This arrangement was considered to provide better accuracy and computational time.

\begin{tabular}{cccccc}
\multicolumn{5}{c}{ Table 4. Design Of Experiments Results Of Model 7} \\
\hline $\begin{array}{c}\text { Learning } \\
\text { Rate }\end{array}$ & $\begin{array}{c}\text { Momentu } \\
\mathrm{m}\end{array}$ & $\begin{array}{c}\text { Training } \\
\text { MSE }\end{array}$ & Test MSE & $\begin{array}{c}\text { Average } \\
\text { MSE }\end{array}$ & $\begin{array}{c}\text { Root } \\
\text { MSE }\end{array}$ \\
0.3 & 0.9 & 0.00051 & 0.000618 & 0.0006 & 0.0237 \\
0.6 & 0.9 & 0.00052 & 0.000628 & 0.0006 & 0.0240 \\
0.9 & 0.9 & 0.00051 & 0.000520 & 0.0005 & 0.0227 \\
0.3 & 0.7 & 0.00051 & 0.000582 & 0.0005 & 0.0234 \\
0.6 & 0.7 & 0.00051 & 0.000588 & 0.0005 & 0.0234 \\
0.9 & 0.7 & 0.00051 & 0.000542 & 0.0005 & 0.0229 \\
0.3 & 0.5 & 0.00051 & 0.000616 & 0.0006 & 0.0237 \\
0.6 & 0.5 & 0.00051 & 0.000608 & 0.0006 & 0.0236 \\
0.9 & 0.5 & 0.00051 & 0.000480 & 0.0005 & 0.0222
\end{tabular}

The forecasting results with Model 7 were compared with the Holt-Winters method. The Holt-Winters method is a classic method known for predicting time series results with seasonal factors and trends or trends [28] [29]. Total 108 time-series data on the productivity of salt fields in Kalianget Sumenep have used the input data. The resulting RMSE value was 0.0395 . Comparison of RMSE values showed that both HoltWinters and ANN methods have a value below 10\%. Therefore, both methods were feasible to use [30]. However, the ANN method still has advantages over the Holt-Winter method because the RMSE value is smaller than the Holt-Winters method.

This study complemented previous works by providing empirical results to support the serial dependence of salt field productivity. In many cases, the salt industry 
stakeholders want to know various factors, such as temperature, seawater quality, sunlight duration, and salt production technology. Also, stakeholders want to see the integration between forecast results and production planning strategies to manage their supply chains better. Therefore, further research needs to include these additional factors in different models and extend the results into integrated planning of the enterprise resource application system.

\section{Conclusion}

This study showed that the proposed model works well in predicting salt field productivity by considering weather factors and determining the optimum ANN parameter values. This study also illustrates how the ANN method can be applied to improve the accuracy of estimates of salt field productivity in supporting supply chain management innovations. To obtain a precise forecast of productivity, it used the rainfall, humidity, and wind speed information over the research area in Sumenep Madura. The most efficient neural network examined is a model with all three variables used as input neurons. Further research needs to include these additional factors in different models and extend the results into the integrated planning of the enterprise resource application system.

\section{Acknowledgments}

This study was conducted with support from the University of Trunojoyo Madura Research Grant 2019.

\section{References}

[1] R. F. Aji and W. M. Suryaningrat, "Faktor-faktor yang mempengaruhi permintaan dan efektivitas kebijakan impor garam indonesia/Ahmad Syariful jamil, Netty Tinaprilla, Suharno," Policy, vol. 534, p. 546, 2017.

[2] M. Effendy and M. Zainuri, "Intensifikasi Lahan Garam Rakyat Di Kabupaten Sumenep. Program Studi Ilmu Kelautan Universitas Trunojoyo Madura " pp. 22-43, 2014.

[3] Y. Adiraga and A. H. Setiawan, "Analisis Dampak Perubahan Curah Hujan, Luas Tambak Garam Dan Jumlah Petani Garam Terhadap Produksi USAha Garam Rakyat Di Kecamatan Juwana Kabupaten Pati Periode 2003-2012," Diponegoro Journal of Economics, vol. 3, pp. 41-53, 2014. https://ejournal3.undip.ac.id/index.php/jme/article/view/5314.

[4] I. R. Suhelmi and P. Indonesia. Badan Penelitian dan Pengembangan Kelautan dan, Garam Madura: tradisi dan potensi usaha garam rakyat: Badan Penelitian dan Pengembangan Kelautan dan Perikanan, Kementerian Kelautan dan Perikanan, 2013..

[5] C. Satryo, "Free Trade Intervention: Political-Economic Intervention on Global Business Environment," Asia-Pacific Management and Business Application, vol. 7, pp. 21-30, 2018. http://doi.org/10.21776/ub.apmba.2018.007.01.3.

[6] S. Chopra and P. Meindl, "Supply chain management. Strategy, planning \& operation," in Das summa summarum des management, ed: Springer, 2007, pp. 265-275. https://doi.org/10.1007/978-3-8349-9320-5_22.

[7] F. Ibrahim, "Integrated Supply Chain Contract Model With Drop-Shipper Players," Jurnal Teknik Industri, vol. 19, pp. 58-72, 2018. https://doi.org/10.22219/JTIUMM.Vol19.No1.58-72. 
[8] I. Masudin and M. S. Kamara, "Electronic Data Interchange and Demand Forecasting Implications on Supply Chain Management Collaboration: A Customer Service Perspective," Jurnal Teknik Industri, vol. 18, pp. 138-148, 2017. https://doi.org/10.22219/JTIUMM.Vol18.No2.138-148.

[9] I. Masudin and M. S. Kamara, "Impact Of Just-In-Time, Total Quality Management And Supply Chain Management On Organizational Performance: A Review Perspective," Jurnal Teknik Industri, vol. 19, pp. 11-20, 2018. https://doi.org/10.22219/JTIUMM.Vol19.No1.11-20.

[10] S. Dharmayanti, S. Suharno, and A. Rifin, "Analisis Ketersediaan Garam Menuju Pencapaian Swasembada Garam Nasional Yang Berkelanjutan (Suatu Pendekatatan Model Dinamik)," Jurnal Sosial Ekonomi Kelautan dan Perikanan, vol. 8, pp. 103-115, 2013. http://dx.doi.org/10.15578/jsekp.v8i1.1201

[11] S. Herman, E. Noor, and D. Mulyadi, "Identifikasi Faktor Kunci Krisis Pada Tataniaga Garam Konsumsi Di Indonesia Menggunakan Proses Jejaring Analitik (Analytic Network Process," Journal of Industrial Research (Jurnal Riset Industri), vol. 8, 2014. http://ejournal.kemenperin.go.id/jri/article/view/154/139.

[12] A. S. Perbangsa, W. Wijaya, A. Amelia, and B. Pardamean, "Model of web-based supply chain management system for salt industry," in 2017 International Conference on Information Management and Technology (ICIMTech), 2017, pp. 232237. https://doi.org/10.1109/ICIMTech.2017.8273543.

[13] D. Chen and D. Ware, "A neural network model for forecasting fish stock recruitment," Canadian Journal of Fisheries and Aquatic Sciences, vol. 56, pp. 2385-2396, 1999. https://doi.org/10.1139/f99-178.

[14] A. Ihwan, "Metode Jaringan Saraf Tiruan Propagasi Balik Untuk Estimasi Curah Hujan Bulanan di Ketapang Kalimantan Barat," Prosiding SEMIRATA 2013, vol. 1, 2013. http://jurnal.fmipa.unila.ac.id/semirata/article/view/743/562.

[15] G. Zhang, B. E. Patuwo, and M. Y. Hu, "Forecasting with artificial neural networks:: The state of the art," International journal of forecasting, vol. 14, pp. 3562, 1998. https://doi.org/10.1016/S0169-2070(97)00044-7.

[16] M. Lydia, S. Suresh Kumar, A. Immanuel Selvakumar, and G. Edwin Prem Kumar, "Linear and non-linear autoregressive models for short-term wind speed forecasting," Energy Conversion and Management, vol. 112, pp. 115-124, 2016. https://doi.org/10.1016/j.enconman.2016.01.007.

[17] S. Ferlito, M. Atrigna, G. Graditi, S. De Vito, M. Salvato, A. Buonanno, et al., "Predictive models for building's energy consumption: An Artificial Neural Network (ANN) approach," in 2015 xviii aisem annual conference, 2015, pp. 1-4. https://doi.org/10.1109/AISEM.2015.7066836.

[18] R. P. S. Hermanto and A. Nugroho, "Waiting-Time Estimation in Bank Customer Queues using RPROP Neural Networks," Procedia Computer Science, vol. 135, pp. 35-42, 2018. https://doi.org/10.1016/j.procs.2018.08.147.

[19] S. Nissen, "Implementation of a fast artificial neural network library (fann)," Report, Department of Computer Science University of Copenhagen (DIKU), vol. 31, p. 29, 2003. http://fann.sourceforge.net/fann.pdf.

[20] C. Igel and M. Hüsken, "Empirical evaluation of the improved Rprop learning algorithms," Neurocomputing, vol. 50, pp. 105-123, 2003. https://doi.org/10.1016/S0925-2312(01)00700-7.

[21] J. Heaton, Introduction to neural networks with Java: Heaton Research, Inc., 2008.

[22] T. Masters, Practical neural network recipes in C++: Morgan Kaufmann, 1993. 
[23] L.-F. Hsieh, S.-C. Hsieh, and P.-H. Tai, "Enhanced stock price variation prediction via DOE and BPNN-based optimization," Expert Systems with Applications, vol. 38, pp. 14178-14184, 2011. https://doi.org/10.1016/j.eswa.2011.04.229.

[24] E. T. Tan, J. R. Tang, and N. A. M. Isa, "Applying Design of Experiment to Optimise Artificial Neural Network for Classification of Cervical Cancer," Journal of Engineering Science, vol. 12, p. 2016. http://web.usm.my/jes/12_2016/JES\%20Vol.\%2012\%202016\%20-\%20Art.\%206(6575).pdf.

[25] F. J. Pontes, G. Amorim, P. P. Balestrassi, A. Paiva, and J. R. Ferreira, "Design of experiments and focused grid search for neural network parameter optimization," $\begin{array}{lllll}\text { Neurocomputing, } & \text { vol. } & 186, & \text { pp. } & 22-34,\end{array}$ https://doi.org/10.1016/j.neucom.2015.12.061.

[26] R. J. Hyndman, "Another look at forecast-accuracy metrics for intermittent demand," Foresight: The International Journal of Applied Forecasting, vol. 4, pp. 43-46, 2006. https://econpapers.repec.org/RePEc:for:ijafaa:y:2006:i:4:p:43-46.

[27] A. Š. Tomić, D. Antanasijević, M. Ristić, A. Perić-Grujić, and V. Pocajt, "Application of experimental design for the optimization of artificial neural network-based water quality model: a case study of dissolved oxygen prediction," Environmental Science and Pollution Research, vol. 25, pp. 9360-9370, 2018. https://doi.org/10.1007/s11356-018-1246-5.

[28] L. F. Tratar and E. Strmčnik, "The comparison of Holt-Winters method and Multiple regression method: A case study," Energy, vol. 109, pp. 266-276, 2016. https://doi.org/10.1016/j.energy.2016.04.115.

[29] V. C. Sugiarto, R. Sarno, and D. Sunaryono, "Sales forecasting using Holt-Winters in Enterprise Resource Planning at sales and distribution module," in 2016 International Conference on Information \& Communication Technology and Systems (ICTS), 2016, pp. 8-13. https://doi.org/10.1109/ICTS.2016.7910264.

[30] D. Fang, Y. Zhang, and K. Spicher, "Forecasting accuracy analysis based on two new heuristic methods and Holt-Winters-Method," in 2016 IEEE International Conference on Big Data Analysis (ICBDA), 2016, pp. 1-6. https://doi.org/10.1109/ICBDA.2016.7509814. 